Transcriptomic analyses in a benthic fish exposed to contaminated estuarine sediments through laboratory and in situ bioassays

Pedro M. Costa, Célia Miguel, Sandra Caeiro, Jorge Lobo, Marta Martins, Ana M. Ferreira, Miguel Caetano, Carlos Vale, T. À. DelValls, et al.

\section{Ecotoxicology}

ISSN 0963-9292

Volume 20

Number 8

Ecotoxicology (2011) 20:1749-1764

DOI 10.1007/s10646-011-0708-z

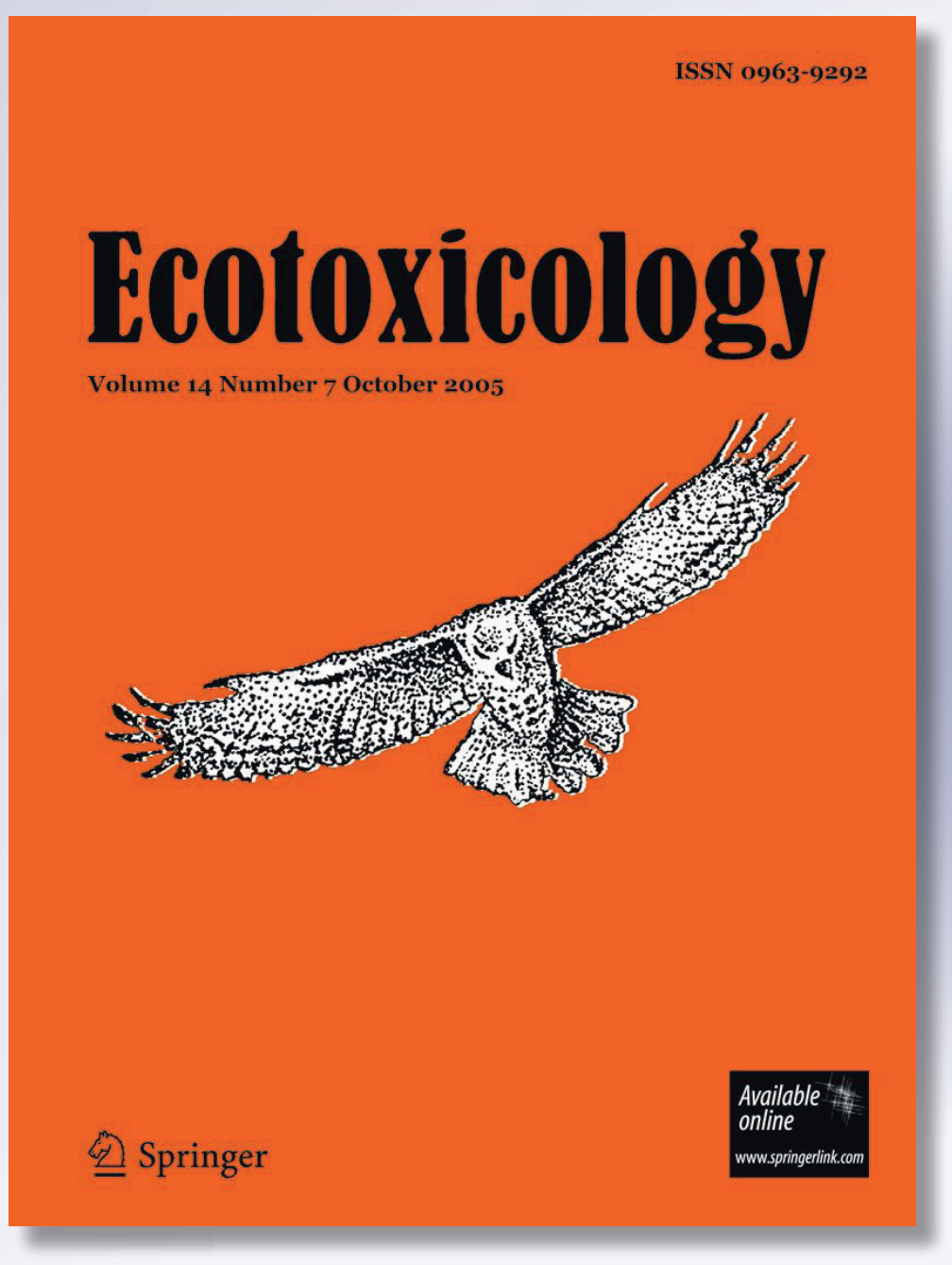

算 Springer 
Your article is protected by copyright and all rights are held exclusively by Springer Science+Business Media, LLC. This e-offprint is for personal use only and shall not be selfarchived in electronic repositories. If you wish to self-archive your work, please use the accepted author's version for posting to your own website or your institution's repository. You may further deposit the accepted author's version on a funder's repository at a funder's request, provided it is not made publicly available until 12 months after publication. 


\title{
Transcriptomic analyses in a benthic fish exposed to contaminated estuarine sediments through laboratory and in situ bioassays
}

\author{
Pedro M. Costa - Célia Miguel - Sandra Caeiro · Jorge Lobo • \\ Marta Martins • Ana M. Ferreira - Miguel Caetano • \\ Carlos Vale • T. À. DelValls • Maria H. Costa
}

Accepted: 29 May 2011/Published online: 10 June 2011

(C) Springer Science+Business Media, LLC 2011

\begin{abstract}
The transcription of contaminant responserelated genes was investigated in juvenile Senegalese soles exposed to sediments from three distinct sites (a reference plus two contaminated) of a Portuguese estuary (the Sado, W Portugal) through simultaneous 28-day laboratory and in situ bioassays. Transcription of cytochrome P450 1A (CYP1A), metallothionein 1 (MT1), glutathione peroxidase (GPx), catalase (CAT), caspase 3 (CASP3) and $90 \mathrm{kDa}$ heat-shock protein alpha (HSP90AA) was surveyed in the liver by real-time PCR. CASP3 transcription analysis was complemented by surveying apoptosis through the TUNEL reaction. After 14 days of exposure, relative transcription was either reduced or decreased in fish exposed to the
\end{abstract}

P. M. Costa $(\bowtie) \cdot$ S. Caeiro $\cdot$ J. Lobo $\cdot$ M. Martins ·

M. H. Costa

IMAR-Instituto do Mar, Departamento de Ciências e Engenharia do Ambiente, Faculdade de Ciências e Tecnologia da

Universidade Nova de Lisboa, 2829-516 Caparica, Portugal

e-mail:pmcosta@fct.unl.pt

C. Miguel

Instituto de Biologia Experimental e Tecnológica/Instituto de Tecnologia Química e Biológica, Universidade Nova de Lisboa (IBET/ITQB-UNL), Apartado 12, 2781-901 Oeiras, Portugal

S. Caeiro

Departamento de Ciências e Tecnologia, Universidade Aberta, Rua da Escola Politécnica, 141, 1269-001 Lisbon, Portugal

M. Martins - A. M. Ferreira - M. Caetano - C. Vale

IPIMAR-INRB, Instituto Nacional dos Recursos Biológicos, Avenida de Brasília, 1449-006 Lisbon, Portugal

T. À. DelValls

UNESCO/UNITWIN/WiCop Chair, Departamento de Química

Física, Facultad de Ciencias del Mar y Ambientales, Universidad de Cádiz, Polígono río San Pedro s/n, 11510 Puerto Real, Cádiz, Spain contaminated sediments, revealing a disturbance stress phase during which animals failed to respond to insult. After 28 days of exposure all genes' transcription responded to contamination but laboratory and in situ assays depicted distinct patterns of regulation. Although sediments revealed a combination of organic and inorganic toxicants, transcription of the CYP1A gene was consistently correlated to organic contaminants. Metallothionein regulation was found correlated to metallic and organic xenobiotic contamination in the laboratory and in situ, respectively. The transcription of oxidative stress-related genes can be a good indicator of general stress but caution is mandatory when interpreting the results since regulation may be influenced by multiple factors. As for MT1, HSP90 up-regulation has potential to be a good indicator for total contamination, as well as the CASP3 gene, even though hepatocyte apoptosis depicted values inconsistent with sediment contamination, showing that programmed cell death did not directly depend on caspase transcription alone.

Keywords Toxicogenomics - Transcriptomics - Solea senegalensis · Quantitative real-time RT-PCR · Apoptosis · Ecological risk assessment

$\begin{array}{ll}\text { Abbreviations } \\ \text { 18S } & \text { Ribosomal subunit 18 } \\ \text { CAT } & \text { Catalase } \\ \text { AI } & \text { Apoptotic indice } \\ \text { CASP3 } & \text { Cysteine-aspartic acid peptidase isoform 3 } \\ \text { CYP1A } & \text { Cytochrome P450 1A } \\ \text { DDD } & \text { Dichloro diphenyl dichloroethane } \\ \text { DDE } & \text { Dichloro diphenyl dichloroethylene } \\ \text { DDT } & \text { Dichloro diphenyl thichloroethane } \\ \text { ERA } & \text { Ecological risk assessment }\end{array}$




$\begin{array}{ll}\text { FF } & \text { Sediment fine fraction } \\ \text { GPx } & \text { Glutathione peroxidase isoform 1 } \\ \text { HSP90AA } & \text { Heat shock protein } 90 \text { kDa alpha } \\ \text { MT1 } & \text { Metallothionein isoform 1 } \\ \text { PAH } & \text { Polycyclic aromatic hydrocarbon } \\ \text { PCB } & \text { Polychlorinated biphenyl } \\ \text { PCD } & \text { Programmed cell death } \\ \text { RT } & \text { Relative transcription ratio } \\ \text { RT-PCR } & \text { Reverse transcription polymerase chain } \\ & \text { reaction } \\ \text { PEL } & \text { Probable effects level guideline } \\ \text { ROS } & \text { Reactive oxygen species } \\ \text { SQG } & \text { Sediment quality guideline } \\ \text { SQG-Q } & \text { Sediment quality guideline quotient } \\ \text { TEL } & \text { Threshold effects level guideline } \\ \text { TOM } & \text { Total organic matter }\end{array}$

\section{Introduction}

Surveying the effects and responses of aquatic organisms to sediment-bound contaminants remains a challenge to environmental toxicologists largely due to the complex geochemical nature of sediments and to the presence of multiple classes of potential toxicants. Besides all the physical and chemical characteristics that determine contaminant bioavailability (therefore modulating its toxicity), the co-exposure to multiple toxicants raises important issues since biomarker responses often yield results that are difficult to interpret, inconsistent with the levels of sediment contamination or even appear to contradict published information regarding their specificity towards a given xenobiotic (see, e.g., Atkinson et al. 2007; Chapman 2007; Hallare et al. 2011). For such reasons, the biomarker approach for ecological risk assessment (ERA) is nowadays aiming at novel methodologies, like "omics", whether more predictive of more mechanistic purposes are intended. These "omics" approaches in environmental toxicology comprise proteomics; metabolomics and transcriptomics, the latest often referred to as toxicogenomics and resulting from the fusion between conventional toxicology and functional genomics, based on advanced molecular biology tools (Gatzidou et al. 2007).

Post-transcriptional mechanisms are influenced by multiple endogenous and exogenous variables; however, transcription is pivotal in the control of gene expression. Although screening of changes in gene transcription through cDNA microarrays is a popular technology for providing information at genome-wide level, its application is costly and restricted to taxa where considerable genomic or expressed sequence tag (EST) information is available.
On the other hand, expression analysis of specific genes by reverse transcription polymerase chain reaction (RT-PCR)related techniques, namely real-time RT-PCR, are sensitive and reliable and can be applied to any species as long as it is possible to design primers from consensus sequences to directly survey the amount of steady-state level of mRNA that should reflect the production and stability of transcripts (see Snell et al. 2003). Thus, for a growing number of ecoor environmental toxicologists, determining changes in transcription regulation of specific genes in fish related to contamination by chemical stressors, especially those concerning classic biomarkers such as CYP1A (cytochrome P450 1A) and MTs (metallothioneins), has been widely employed as an alternative to traditional methods of protein determination (Hallare et al. 2011). Many such studies considered piscine species in a wide variety of scenarios, from Antarctic waters (Miller et al. 1999) to estuarine and freshwater ecosystems, with feral animals or those subjected to laboratory and in situ (field) bioassays (e.g. Wirgin and Waldman 1998; Brammel and Wigginton 2010). The success of this approach to study the mechanisms behind exposure to complex mixtures of xenobiotics has already been demonstrated (e.g. Filby et al. 2007, regarding the estrogenic effects of effluents). Amongst such research lie sediment risk assessment studies through fish-based bioassays and, within these, assays performed with flatfish (Teleostei: Pleuronectiformes), which are gaining terrain due to the benthic nature of these animals, as well as their ecological importance and economical value. Still, many gaps persist in the knowledge of their genomics, leading to a growing effort to enforce novel molecular tools, among which transcriptomics earned a particular importance (Cerdà et al. 2010).

The Senegalese sole (Solea senegalensis Kaup, 1858), is a common species in the Iberian Peninsula, with a considerable economical value, including for aquaculture. The species occupies sandy-muddy bottoms of coastal areas and estuaries, particularly important for breeding and nursing (Cabral 2000). A considerable number of research reports sprung out in the past using this species as test subject. Although most of these studies relate to aquaculture, many environmental toxicological studies focusing on more classical biomarkers can be found, aiming at the fundamental mechanisms of exposure (for instance Chairi et al. 2010; Kalman et al. 2010) and at the biomonitoring of estuarine sediments (e.g. Riba 2004; Costa et al. 2009a, b; Oliva et al. 2010). In addition, some successful attempts using "omic" approaches can already been found, although most also relate to aquaculture, such as transcription analysis by cDNA microarrays and PCR techniques (Manchado et al. 2008; Osuna-Jiménez et al. 2009; PrietoÁlamo et al. 2009 and a few others) and proteomics (Forné et al. 2009; Salas-Leiton et al. 2009; Costa et al. 2010). 
Despite the growing focus on this species for environmental monitoring in SW Europe, comparable to the importance of flounder (Platichthys flesus) in northern countries, few genomic resources are presently available posing serious constraints for surveys at genome-wide level. For such purpose, the identification and characterization of genes responsive to environmental toxicants can be a valuable contribution to understand the underlying biological mechanisms of toxicity and to develop up-todate strategies for ERA.

The main goals of the present work consist of: (i) to assess changes in the transcription profiles of a set of toxicologically-relevant genes in S. senegalensis exposed to estuarine sediments; (ii) to seek for relationships between these changes and the levels of sediment contamination; (iii) to contribute to the understanding of the mechanistics of exposure to contaminant mixtures through the interpretation of gene transcription patterns and (iv) to compare laboratory and in situ bioassays. For the purpose, the genes coding for five (out of six) response proteins were identified and partially characterized at the sequence level for the first time in this species and their transcripts analysed and integrated with sediment quality guidelines.

\section{Methods and materials}

Study area and experimental design

The study area (the Sado estuary, W Portugal) consists of a large basin of great socio-economical importance. The estuary is historically subjected to many sources of anthropogenic pollution: urban (from the city of Setúbal); industrial (from the city's heavy-industry belt that includes chemical plants, a thermoelectrical unit, shipyards, ore deployment facilities and others) and from runoffs from the upstream agriculture grounds. A large part of the estuary is classified as a natural reserve and the area is also very important for tourism, fisheries and maritime transport. The conjugation of all these factors has dictated the need to enforce environmental monitoring in order to develop efficient environment management policies (refer to Caeiro et al. 2009 for an ERA strategy for the estuary).

Three sites of the study area, all within $100 \mathrm{~m}$ from shore, were chosen according to their geographical location (Fig. 1) and to previous research (e.g. Caeiro et al. 2009; Costa et al. 2009a). A reference (clean) site (R) was chosen for being the farthest from pollution sources. Two contaminated sites were selected, located at the city of Setúbal's important commercial harbour (site $\mathrm{C}_{1}$ ) and off Setúbal's heavy-industry area (site $\mathrm{C}_{2}$ ). Sediments were collected by scuba diving from a depth of 7-9 m. Sediment collection and bioassays were performed on May 2007.
Fresh sediment samples were divided for the laboratory assays and chemical characterization (see below).

Juvenile hatchery-brood Solea senegalensis were exposed to sediments from the three sites through simultaneous laboratory and in situ 28-day bioassays (fish standard length $=61.0 \pm 8.4 \mathrm{~mm}$ ). The laboratory assays were performed in duplicate with a recirculation arrangement of 15-1 capacity white polyvinyl tanks with blunt edges where 21 of fresh sediments (providing a surface of approximately $525 \mathrm{~cm}^{2}$ ) plus 121 of clean seawater were allocated, following previous assays with the species (Costa et al. 2009a). The photoperiod was set at $12 \mathrm{~h}$ light:dark and a weekly $25 \%$ water change was applied to ensure constancy of water quality parameters with minimal removal of suspended particles and dissolved contaminants: temperature was set at $18 \pm 1^{\circ} \mathrm{C}$, salinity $=$ $32.1 \pm 0.3, \mathrm{pH} 8.0 \pm 0.1$, oxygen saturation $=56.5 \pm$ $0.2 \%$ (supplied by constant aeration) and total ammonia was maintained within $1.6 \pm 0.6 \mathrm{mg} \mathrm{l}^{-1}$ (the toxic unionized ammonia was restrained at $0.04 \pm 0.02 \mathrm{mg} \mathrm{l}^{-1}$ ). Fish were fed daily with commercial M2 grade pellets (from Sorgal, Portugal). Sediments were allowed to settle for $48 \mathrm{~h}$ before the beginning of the assay. Twenty randomly-selected animals were distributed per replica. The in situ assays were prepared using $90 \times 90 \times 30 \mathrm{~cm}$ PVC plastic cages lined with a $5 \mathrm{~mm}$ plastic mesh. Each cage was divided into two equal-sized compartments that were regarded as replicates. Twenty random-selection animals were allocated in each compartment. The cages were placed over the bottom at each site with scuba equipment in order to ensure direct contact with the sediment. Sampling was scheduled for days $0\left(\mathrm{~T}_{0}\right), 14\left(\mathrm{~T}_{14}\right)$ and $28\left(\mathrm{~T}_{28}\right)$, with five individuals per replica being collected and euthanized by cervical sectioning prior to liver excision. Day 0 animals consisted of ten individuals retrieved from the rearing tanks.

Sediment characterization and contamination profiles

Sediments were characterized for redox potential (Eh), fine particle $(<67 \mu \mathrm{m})$ fraction $(\mathrm{FF})$ and total organic matter (TOM) by electrode measurement (immediately after collection), hydraulic sieving (after disaggregation with pyrophosphate) and organic carbon combustion (at $\approx 500^{\circ} \mathrm{C}$ ), respectively. Sediment inorganic (element) contaminants (arsenic, cadmium, chromium, copper, lead, manganese, nickel and zinc) were determined by inductively coupled plasma mass spectrometry after acid digestion in closed Teflon vials (Caetano et al. 2007). Total mercury was determined by atomic absorption spectrometry with pyrolysis and gold amalgamation according to Costley et al. (2000). The procedures were validated by analysis of the reference sediments MESS-2 and PACS-2 
Fig. 1 Map of study area (the Sado estuary, W Portugal) showing the relative position of the assay and sediment collection sites (filled circle): $\mathrm{R}$ (reference) plus $\mathrm{C}_{1}$ and $\mathrm{C}_{2}$ (contaminated)

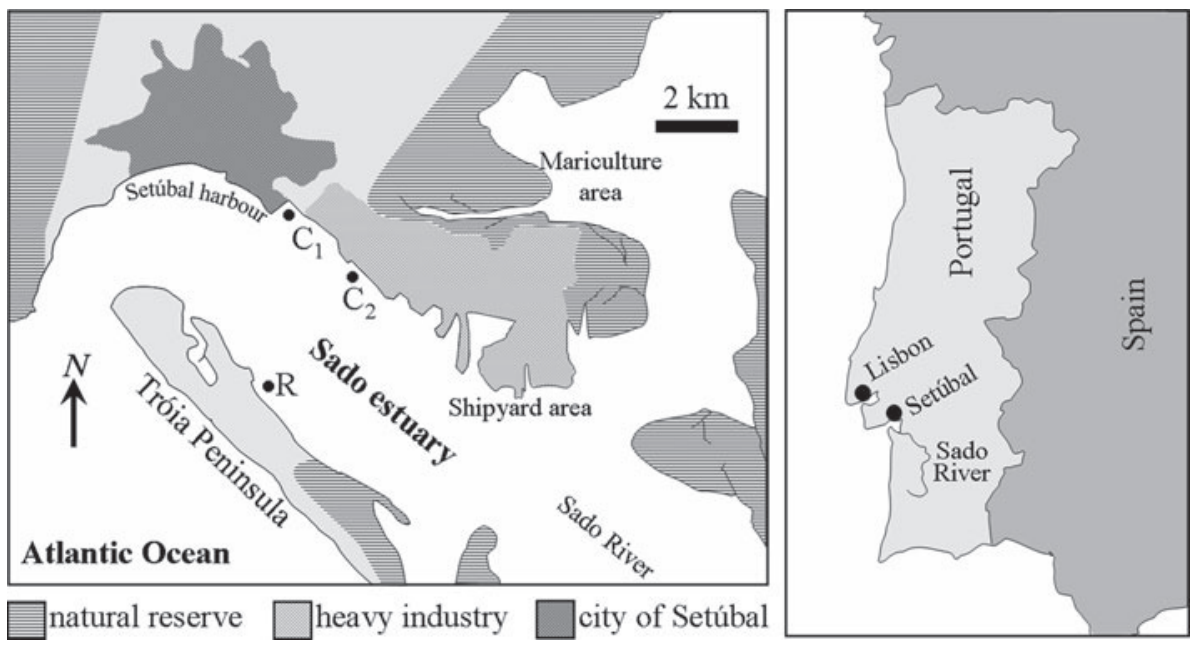

(National Research Council, Canada) and MAG-1 (US Geological Survey, USA). Sediment PAHs was analysed by gas chromatography-mass spectrometry (GC-MS) after Soxhlet-extraction with an acetone + hexane $(1: 1 \mathrm{v} / \mathrm{v})$ mixture as described by Martins et al. (2008). Organochlorines (PCBs and DDT plus its main metabolites) were determined by GC with electron capture detection (GCECD) after Soxhlet extraction with $n$-hexane and column fractioning, following (Ferreira et al. 2003). The quantification of organic contaminants was validated by analysis of the SRM 1941b reference sediment (National Institute of Standards and Technology, USA).

RNA isolation and cDNA synthesis

Total RNA was isolated from $\approx 5$ to $10 \mathrm{mg}$ liver samples of three randomly-selected individuals from each test and sampling time with the spin column-based RNeasy Mini Kit (Qiagen), following instructions from manufacturer, and including a RNA clean-up step with the RNase-Free DNase Set (Qiagen) to eliminate residual genomic DNA. Total RNA was quantified and analysed for purity (assessed by the $260 / 280 \mathrm{~nm}$ absorbance ratio) with a NanoDrop 1000 spectrophotometer (Thermo Scientific). RNA quality was also verified by agarose gel electrophoresis. Aliquots containing the same amount of total RNA were pooled per experimental treatment and sampling time. cDNA was synthesized by reverse transcription from $1 \mu \mathrm{g}$ pooled RNA using the Transcriptor High Fidelity cDNA Synthesis Kit (Roche Applied Science) according to manufacturer instructions.

Primer design and cDNA sequencing

Degenerate primers for $S$. senegalensis CYP1A (cytochrome P450 1A), MT1 (metallothionein 1), CAT (catalase), GPx (glutathione peroxidase 1) and CASP3 (caspase
3) cDNAs were designed based on the alignment of available teleost and Rattus norvegicus cDNA sequences deposited in GenBank public database using the software MEGA4 (Tamura et al. 2007). For sequencing, target gene amplification was done by standard PCR from pooled cDNA aliquots. Sequencing was done with a $3730 \mathrm{XL}$ DNA analyzer (Applied Biosystems). CYP1A, MT1 and CAT were sequenced directly from PCR products but GPx and CASP 3 required previous cloning in the M13 vector. After homology confirmation (Table 1) with database sequences using the software Blast (Altschul et al. 1990), the edited and trimmed cDNA sequences for CYP1A1, MT1, CAT, GPx and CASP3 genes were deposited in the GenBank (National Institutes of Health of the USA) public access data base (Table 2). Specific primers were afterwards designed for real-time PCR. Primers for S. senegalensis HSP90AA (heat shock protein $90 \mathrm{kDa}$ isoform alpha, termed inducible) and the housekeeping (reference) 18S (ribosomal subunit 18) genes were obtained from Manchado et al. (2008) and Cerdà et al. (2008), respectively. Gene selection was based on the potential function of respective proteins in response to toxicant-induced stress: anti-oxidative (GPx and CAT); metal-binding and detoxification (MT1); detoxification of organic contaminants (CYP1A); protein unfolding and chaperone (HSP90AA) and apoptosis (CASP3). Primer specificity, annealing temperature and amplicon size were confirmed by agarose gel electrophoresis (Table 2).

\section{Quantitative real-time PCR}

Quantitative real-time PCR was performed on a 96-well LightCycler 480 II Instrument using the SYBR Green I Master Mix for real-time PCR (all from Roche Applied Science). Each reaction $(20 \mu \mathrm{l})$ was prepared with $10 \mu \mathrm{l}$ Master Mix, $7 \mu$ PCR grade ultra-pure water, $1 \mu$ of each primer's $10 \mu \mathrm{M}$ solution and $1 \mu \mathrm{l}$ template cDNA sample. 
Table 1 Sequenced S. senegalensis target genes' complete cDNAs or ESTs and respective match scores

\begin{tabular}{|c|c|c|c|c|c|c|c|}
\hline \multirow[t]{2}{*}{ Gene ID } & \multicolumn{2}{|c|}{ cDNA/mRNA sequence } & \multicolumn{2}{|l|}{ Similar to } & \multicolumn{3}{|c|}{ Blast results } \\
\hline & Size (bp) & Status & Species & GenBank accession & $\%$ ID & Score & e-Value \\
\hline CYP1A & 591 & Partial & Paralichthys olivaceus & EF451958.1 & 88 & 750 & 0.0 \\
\hline MT1 & 183 & Complete & Pleuronectes platessa & X56743.1 & 90 & 254 & $8.0 \times 10^{-66}$ \\
\hline GPx & 385 & Complete & Oplegnathus fasciatus & AY734530.1 & 86 & 490 & $1.0 \times 10^{-136}$ \\
\hline CAT & 432 & Partial & Oplegnathus fasciatus & AY734528.1 & 90 & 523 & $2.0 \times 10^{-146}$ \\
\hline CASP3 & 352 & Partial & Danio rerio & NM_131877.2 & 92 & 130 & $4.0 \times 10^{-11}$ \\
\hline
\end{tabular}

Table 2 Primers used for quantitative real-time PCR and relevant data

\begin{tabular}{|c|c|c|c|c|c|}
\hline Gene ID & GenBank accession & Primer & Primer sequence $\left(5^{\prime}-3^{\prime}\right)$ & Amplicon size (bp) & $\mathrm{T}_{\mathrm{ann}}\left({ }^{\circ} \mathrm{C}\right)^{\mathrm{c}}$ \\
\hline CYP1A & GU946412 & $\begin{array}{l}\text { Forward } \\
\text { Reverse }\end{array}$ & $\begin{array}{l}\text { TGGGCAGCAAACCTTACCTG } \\
\text { CTGTGCTGAAGGCCAGACTC }\end{array}$ & 213 & 60 \\
\hline MT1 & GU946410 & $\begin{array}{l}\text { Forward } \\
\text { Reverse }\end{array}$ & $\begin{array}{l}\text { TTGCGAATGCTCCAAGACTG } \\
\text { GTCGCATGTCTTCCCTTTAC }\end{array}$ & 157 & 52 \\
\hline GPx & HM068301 & $\begin{array}{l}\text { Forward } \\
\text { Reverse }\end{array}$ & $\begin{array}{l}\text { ATGAACGAGCTGCACTGTCG } \\
\text { AGATAGACAAACAAGGGGTGTG }\end{array}$ & 212 & 55 \\
\hline CAT & GU946411 & $\begin{array}{l}\text { Forward } \\
\text { Reverse }\end{array}$ & $\begin{array}{l}\text { TGAGCAGGCTGAAAAGTTCC } \\
\text { GGCATGTTACTTGGGTCAAAG }\end{array}$ & 162 & 52 \\
\hline CASP3 & HQ115741 & $\begin{array}{l}\text { Forward } \\
\text { Reverse }\end{array}$ & $\begin{array}{l}\text { CATCATCAACAACAAGAACTTTGACG } \\
\text { ATGGTCTTCCTCCGAGGCTT }\end{array}$ & 181 & 59 \\
\hline HSP90AA $^{\text {a }}$ & AB367526 & $\begin{array}{l}\text { Forward } \\
\text { Reverse }\end{array}$ & $\begin{array}{l}\text { GACCAAGCCTATCTGGACCCGCAAC } \\
\text { TTGACAGCCAGGTGGTCCTCCCAGT }\end{array}$ & 105 & 52 \\
\hline $18 \mathrm{~S}^{\mathrm{b}}$ & AM882675 & $\begin{array}{l}\text { Forward } \\
\text { Reverse }\end{array}$ & $\begin{array}{l}\text { GAATTGACGGAAGGGCACCACCAG } \\
\text { ACTAAGAACGGCCATGCACCACCAC }\end{array}$ & 148 & 55 \\
\hline
\end{tabular}

${ }^{a}$ From Manchado et al. (2008)

b From Cerdà et al. (2008)

c Primer annealing temperature set for real-time PCR

All analyses were performed in triplicate in order to obtain a $n=3$ per gene, sampling time and experimental test. The gene for the ribosomal protein $18 \mathrm{~S}$ was considered for normalization. The PCR efficiencies $(E)$ and relative transcription of the target genes were calculated as described by Pfaffl (2001). Accordingly, efficiency is estimated as:

$E=10^{-\frac{1}{\text { slope }}}$

The slope is returned from the calibration curves for each target gene, obtained from six serial dilutions of a pooled cDNA sample (lowest $r^{2}=0.98$ ). According to Pfaffl (2001), the $E$ values for each target gene were used to compute the relative transcription (RT) for exposed fish (sample) relatively to fish collected at $\mathrm{T}_{0}$ (calibrator), which is described as the ratio:

$\mathrm{RT}=\frac{\left(E_{\text {target }}\right)^{\Delta C_{t}(\text { calibrator-sample })}}{\left(E_{\text {reference }}\right)^{\Delta C_{t}(\text { calibrator-sample })}}$

where $C_{t}$ represents the threshold cycle and $E_{\text {reference }}$ the efficiency for the reference gene $18 \mathrm{~S}$. $\mathrm{T}_{0}$ animals were selected as the calibrator group for statistical purposes. The $C_{t}$ estimates and primer melting curves (for confirmation of specific amplification) were obtained using the LightCycler 480 II manufacturer software.

Estimation of apoptotic indices

As a complement to the CASP3 apoptosis-related gene analysis, apoptotic cells in fish hepatic parenchyma were identified through the TUNEL reaction (TdT-mediated dUTP-X nick end labelling) using the In Situ Cell Death Detection Kit with fluorescein as fluorochrome (Roche Applied Science) from paraffin-embedded sections, as indicated by the manufacturer. In brief: fresh liver portions from three randomly-selected individuals from each test and sampling time, including $\mathrm{T}_{0}$ animals (meaning $n=3$ per experimental condition) were fixed in BouinHollande's fixative, dehydrated in a progressive series of ethanol and embedded in paraffin (xylene was used for intermediate impregnation). Sections (3 $\mu \mathrm{m}$ thick) were 
dehydrated, permeabilized with a proteinase $\mathrm{K}$ (Invitrogen) solution $\left(20 \mu \mathrm{g} \mathrm{ml}^{-1}\right.$ for $30 \mathrm{~min}$ at $\left.60^{\circ} \mathrm{C}\right)$ and stained through the TUNEL reaction for $1 \mathrm{~h}$ at $37^{\circ} \mathrm{C}$. Analyses were performed with a DMLB model microscope adapted for epifluorescence with an EL6000 light source for mercury short-arc reflector lamps and fitted with an I3 filter for fluorescein (Leica Microsystems). Observations were made from at least eight sequential sections on each slide. The apoptotic indice (AI) was estimated as the number of apoptotic (TUNEL-positive) cells per section $\mathrm{mm}^{2}$. The identification of apoptotic cells was based on the intensity of fluorescence and morphological criteria (after Häcker 2000).

Statistics and integration of data

The sediment contaminants' potential to cause adverse effects to organisms was determined by comparison of the measured concentrations with the Threshold Effects Level (TEL) and the Probable Effects Level (PEL) Sediment Quality Guidelines (MacDonald et al. 1996). The overall potential impact of each class of contaminants was inferred from the Sediment Quality Guideline Quotient (SQG-Q), which was calculated as defined by Long and MacDonald (1998) through the formula:

SQG-Q $=\frac{\sum_{i=1}^{n} \frac{C_{i}}{\mathrm{PEL}_{i}}}{n}$

where $C_{i}$ is the measured concentration of the $i$ th contaminant, $\mathrm{PEL}_{i}$ the available PEL guideline for the contaminant $i$ and $n$ the number of contaminants in the considered class or group. Each tested sediment was given an overall rating according to the SQG-Q combining all contaminant classes as proposed by MacDonald et al. (2004): SQG-Q < 0.1-unimpacted; $0.1<$ SQG-Q $<1-$ moderately impacted; SQG-Q $>1$-highly impacted.

By failing to comply with the parametric ANOVA assumptions of homocedascity and normality of data, the non-parametric Mann-Whitney $U$-test was employed to assess significant differences in gene expression and apoptotic indices between fish exposed to the contaminated sediment $\mathrm{C}_{1}$ and $\mathrm{C}_{2}$ and fish exposed to the reference sediment (R). The non-parametric Kruskall-Wallis ANOVA by ranks $H$ statistic was computed to verify overall differences between laboratory and field-exposed fish. The non-parametric Spearman's rank-order correlation $\rho$ statistic was employed to find correlations between gene expression data and the sediments' potential to cause adverse effects, given by the SQG-Q values. A significance level of $\alpha=0.05$ was considered for all analyses. Statistics were performed according to Zar (1998), using the software Statistica (Statsoft). Cluster analyses on gene expression data were performed with the software DAnTE (Polpitiya et al. 2008).

\section{Results}

Sediment characterization

The reference sediment $(\mathrm{R})$ was confirmed to be overall unimpacted by xenobiotics, being the least anoxic and also the sediment with the lesser proportion of TOM and FF (Table 3). Sediment from site $C_{1}$ was found to be the most impacted, being the most contaminated by inorganic substances (metals and metalloids). Sediment $\mathrm{C}_{2}$ was found the most contaminated by PAHs and organochlorines. However, both sediments $\mathrm{C}_{1}$ and $\mathrm{C}_{2}$ could be globally considered as moderately impacted. Arsenic (As) copper $(\mathrm{Cu})$, total mercury $(\mathrm{Hg})$, nickel, lead $(\mathrm{Pb})$ and zinc $(\mathrm{Zn})$ were the main elements of concern in the contaminated sediments whereas 4- and 5-ring PAHs were the most important organic xenobiotics. Organochlorine concentrations were higher in sediment $\mathrm{C}_{2}$, with especial relevance for DDTs (with $p p^{\prime}$ DDT presenting a concentration above the TEL threshold).

\section{Gene transcription analyses}

Different levels of gene transcription relative to R-tested fish were observed, not only between laboratory and in situ assays but also between animals collected at $\mathrm{T}_{14}$ and $\mathrm{T}_{28}$ (Fig. 2). Only the transcription patterns for CAT failed to reveal significant differences between laboratory and fish exposed in situ at both $\mathrm{T}_{14}$ and $\mathrm{T}_{28}$. The relative expression for CASP3 was significantly different between the two types of assays at both sampling times (Kruskall-Wallis $H$, $p<0.05)$. The transcription of all other genes revealed significant differences only at $\mathrm{T}_{28}$ (Kruskall-Wallis $H$, $p<0.05)$. In addition, differences were observed between fish exposed to sediments $\mathrm{C}_{1}$ (contaminated by inorganic and organic xenobiotics) and $\mathrm{C}_{2}$ (the most contaminated by organic substances). The highest levels of relative transcription for the laboratory assays were observed to occur in fish exposed to sediment $\mathrm{C}_{2}$ for 28 days, namely for CAT and CYP1A (approximately 37- and 18-fold, respectively). Regarding the in situ assays, exposure to the two contaminated sediments caused down-regulation of MT1, GPx and HSP90AA at $\mathrm{T}_{14}$ and of CAT and CASP3 only for test $\mathrm{C}_{1}$. Only CYP1A transcription depicted a similar pattern at both sampling times in field tested fish but only the exposure to $\mathrm{C}_{2}$ elicited significant up-regulation ( $\approx 3-4$ fold comparatively to R-tested fish). The highest relative transcription during the in situ assays was observed for the HSP90AA gene, in fish tested at site $\mathrm{C}_{2}$ 
Table 3 General

characterization and risk assessment (by comparison with available guidelines for the analysed contaminants) for the sediments collected from the three surveyed sites: $\mathrm{R}$ (reference) and $\mathrm{C}_{1}$ plus $\mathrm{C}_{2}$ (contaminated)
The sediment quality guidelines TEL and PEL were obtained from Macdonald et al. (1996). Only the contaminant concentrations for which guidelines are available are shown

$P E L$ probable effects level sediment quality guideline, $T E L$ threshold effects level sediment quality guideline, $S Q G$ - $Q$ sediment quality guideline quotients (refer to formula 3)

* Values above TEL, ** Values above PEL, ${ }^{\dagger}$ The provided mercury concentrations relate to total $\mathrm{Hg}$ (inorganic plus organic species)

Overall ratings: ${ }^{a}$ Unimpacted,

${ }^{\mathrm{b}}$ Moderately impacted

\begin{tabular}{|c|c|c|c|c|c|}
\hline & \multicolumn{5}{|l|}{ Site } \\
\hline & $\mathrm{R}$ & $\mathrm{C}_{1}$ & $\mathrm{C}_{2}$ & & \\
\hline TOM $(\%)$ & 2.3 & 10.2 & 7.2 & & \\
\hline $\mathrm{FF}(\%)$ & 22.5 & 95.6 & 75.8 & & \\
\hline Eh $(\mathrm{mV})$ & -140 & -300 & -312 & & \\
\hline \multirow[t]{2}{*}{ Contaminant concentration } & & & & \multicolumn{2}{|c|}{ SQGs } \\
\hline & & & & TEL & PEL \\
\hline \multicolumn{6}{|c|}{ Inorganic $\left(\mu \mathrm{g} \mathrm{g}^{-1}\right.$ sediment $\left.\mathrm{dw}\right)$} \\
\hline \multicolumn{6}{|l|}{ Metalloid } \\
\hline As & $5.20 \pm 0.10$ & $23.98 \pm 0.48^{*}$ & $20.69 \pm 0.41 *$ & 7.24 & 41.6 \\
\hline \multicolumn{6}{|l|}{ Metal } \\
\hline $\mathrm{Cd}$ & $0.06 \pm 0.00$ & $0.26 \pm 0.01$ & $0.29 \pm 0.01$ & 0.68 & 4.21 \\
\hline $\mathrm{Cr}$ & $18.14 \pm 0.36$ & $80.73 \pm 1.61 *$ & $51.70 \pm 1.03$ & 52.3 & 160 \\
\hline $\mathrm{Cu}$ & $28.20 \pm 0.56^{*}$ & $172.72 \pm 3.45^{* *}$ & $95.31 \pm 1.91 *$ & 18.7 & 108 \\
\hline $\mathrm{Hg}^{\dagger}$ & $0.11 \pm 0.00$ & $0.69 \pm 0.01^{*}$ & $0.71 \pm 0.01^{* *}$ & 0.13 & 0.7 \\
\hline $\mathrm{Ni}$ & $7.31 \pm 0.15$ & $33.30 \pm 0.67 *$ & $20.49 \pm 0.41^{*}$ & 15.9 & 42.8 \\
\hline $\mathrm{Pb}$ & $18.57 \pm 0.37$ & $55.19 \pm 1.10^{*}$ & $43.76 \pm 0.88^{*}$ & 30.2 & 112 \\
\hline $\mathrm{Zn}$ & $72.29 \pm 1.45$ & $364.83 \pm 7.30 * *$ & $269.31 \pm 5.39^{*}$ & 124 & 271 \\
\hline$S Q G-Q_{\text {inorganic }}$ & 0.16 & 0.79 & 0.58 & & \\
\hline \multicolumn{6}{|l|}{ Organic (ng g ${ }^{-1}$ sediment $\mathrm{dw}$ ) } \\
\hline \multicolumn{6}{|l|}{ PAH } \\
\hline \multicolumn{6}{|l|}{ 3-ring } \\
\hline Acenaphthylene & $0.79 \pm 0.13$ & $2.38 \pm 0.40$ & $2.18 \pm 0.37$ & 5.87 & 128 \\
\hline Acenaphthene & $0.73 \pm 0.12$ & $12.25 \pm 2.08^{*}$ & $7.83 \pm 1.33^{*}$ & 6.71 & 88.9 \\
\hline Fluorene & $1.19 \pm 0.20$ & $15.33 \pm 2.61$ & $9.95 \pm 1.69$ & 21.2 & 144 \\
\hline Phenanthrene & $10.28 \pm 1.75$ & $63.87 \pm 10.86$ & $59.91 \pm 10.18$ & 86.7 & 544 \\
\hline Anthracene & $2.30 \pm 0.39$ & $21.00 \pm 3.57$ & $20.84 \pm 3.54$ & 46.9 & 245 \\
\hline \multicolumn{6}{|l|}{ 4-ring } \\
\hline Fluoranthene & $23.34 \pm 3.97$ & $315.71 \pm 53.67^{*}$ & $345.24 \pm 58.69^{*}$ & 113 & 1494 \\
\hline Pyrene & $21.51 \pm 3.66$ & $263.18 \pm 44.74 *$ & $286.33 \pm 48.68^{*}$ & 153 & 1398 \\
\hline Benzo(a)anthracene & $3.70 \pm 0.63$ & $81.25 \pm 13.81^{*}$ & $93.99 \pm 15.98^{*}$ & 74.8 & 693 \\
\hline Chrysene & $2.35 \pm 0.40$ & $41.06 \pm 6.98$ & $46.68 \pm 7.94$ & 108 & 846 \\
\hline \multicolumn{6}{|l|}{ 5-ring } \\
\hline Benzo(a)pyrene & $5.42 \pm 0.92$ & $101.86 \pm 17.32 *$ & $126.76 \pm 21.55^{*}$ & 88.8 & 763 \\
\hline Dibenzo(a,h)anthracene & $0.66 \pm 0.11$ & $13.32 \pm 2.26^{*}$ & $13.93 \pm 2.37 *$ & 6.22 & 135 \\
\hline$S Q G-Q_{P A H}$ & 0.01 & 0.11 & 0.12 & & \\
\hline \multicolumn{6}{|l|}{ PCB } \\
\hline Total PCBs & $0.80 \pm 0.14$ & $7.91 \pm 1.34$ & $11.97 \pm 2.04$ & 21.6 & 189 \\
\hline$S Q G-Q_{P C B}$ & 0 & 0.04 & 0.06 & & \\
\hline \multicolumn{6}{|l|}{ DDT } \\
\hline$p p^{\prime} \mathrm{DDD}$ & $<$ d.l. & $0.37 \pm 0.06$ & $0.71 \pm 0.12$ & 1.22 & 7.81 \\
\hline$p p^{\prime} \mathrm{DDE}$ & $<$ d.l. & $<$ d.l. & $0.59 \pm 0.10$ & 2.07 & 374 \\
\hline$p p^{\prime} \mathrm{DDT}$ & $<$ d.l. & $<$ d.l. & $1.22 \pm 0.21 *$ & 1.19 & 4.77 \\
\hline$S Q G-Q_{D D T}$ & 0 & 0.02 & 0.12 & & \\
\hline$S Q G-Q_{\text {Organic }}$ & 0.01 & 0.09 & 0.11 & & \\
\hline$S Q G-Q_{\text {Total }}$ & $0.06^{\mathrm{a}}$ & $0.33^{\mathrm{b}}$ & $0.28^{\mathrm{b}}$ & & \\
\hline
\end{tabular}

after 28 days of exposure ( $\approx 6$ fold). Cluster analyses (Fig. 3) confirmed the differences between sampling times, assay types and exposure to the contaminated sediments, revealing distinct patterns of gene transcription, however with common trends, such as the consistent allocation of CAT and CYP1A within the same clusters. 
Fig. 2 Average relative gene transcription \pm standard deviation (in arbitrary units) in the livers of $S$. senegalensis exposed to the reference (R) and contaminated $\left(\mathrm{C}_{1}\right.$ and $\left.\mathrm{C}_{2}\right)$ sediments for CYP1A1, MT1, GPx, CAT, CASP 3 and HSP90AA genes. [*] indicate significant differences from fish exposed to the reference sediment at the same assay type and sampling time $(n=3$; Mann-Whitney $U, p<0.05$ ). Fish collected at $\mathrm{T}_{0}$ are the calibrator group

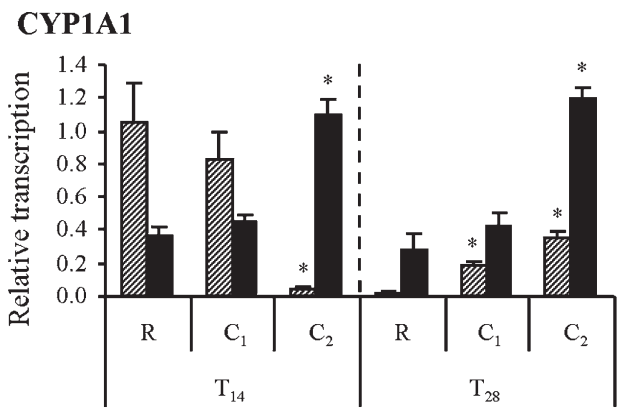

Test and sampling time

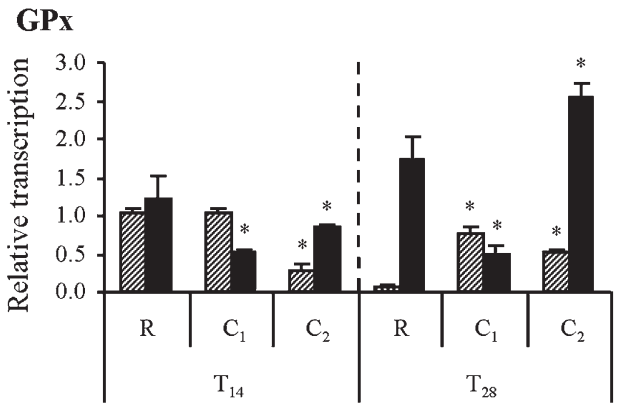

Test and sampling time

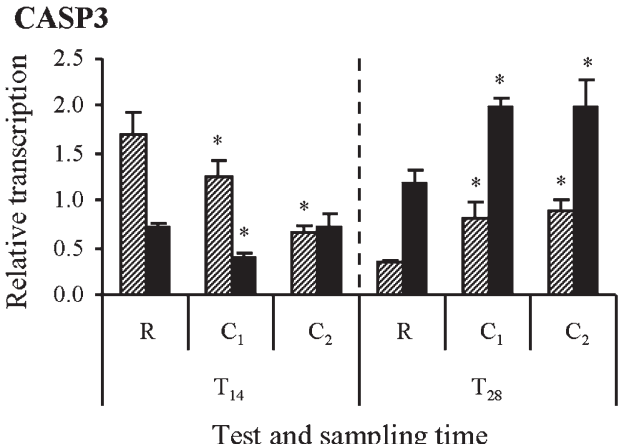

\section{MT1}

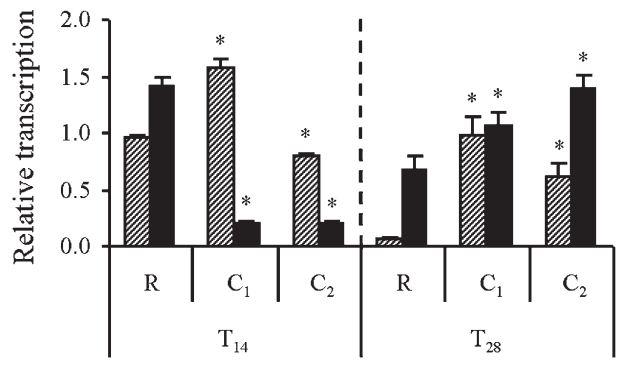

Test and sampling time

\section{CAT}

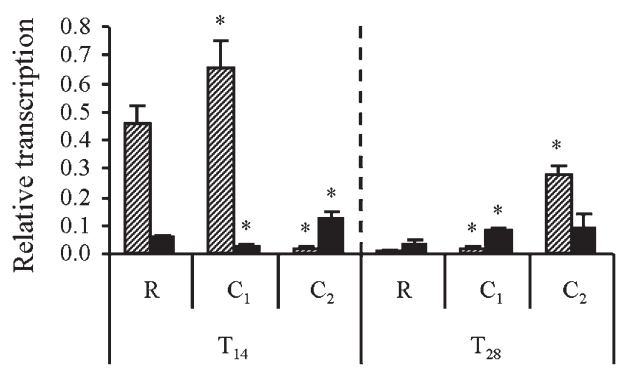

Test and sampling time

HSP90AA

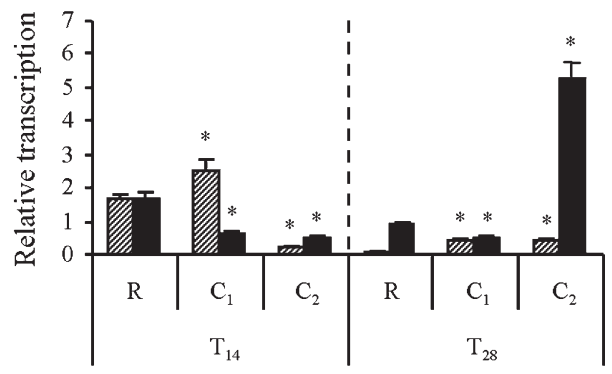

Test and sampling time

Assay type:

Laboratory

In situ

\section{Hepatocyte apoptosis}

A different pattern of hepatocyte apoptosis (Fig. 4a) was observed between laboratory and in situ tested fish. With the exception of a decrease in the apoptotic indice in fish exposed to sediment $\mathrm{C}_{1}$ for 14 days, the field assays did not reveal any significant change in the apoptotic indice of animals exposed to the contaminated sediments relatively to the reference test at either time point (Fig. 4b). However, laboratory exposure to the sediment $\mathrm{C}_{2}$ increased liver cell apoptosis in animals exposed for 14 and 28 days, whereas apoptosis was found to be reduced in comparison to R-tested fish after 28 days of exposure to sediment $\mathrm{C}_{1}$.
Correlating gene transcription to sediment risk

Correlation analysis between the potential to cause adverse effects of each surveyed class of sediment contaminants (organic, inorganic and total) and the gene transcription plus AI data retrieved from the exposed fish revealed, after 14 days of exposure, that only CYP1A in field-tested fish was positively correlated to organic xenobiotics (Table 4). Also, the apoptotic indice estimated for the same assay and sampling time was positively correlated to the relative transcription of MT1, GPx and CASP3. Conversely, at $\mathrm{T}_{28}$, CYP1A regulation was found to be correlated to the organic contaminants' SQG-Q for both types of assays, as well as CAT in laboratory-tested animals. Interestingly, the 
Fig. 3 Cluster analyses on the relative transcription of all surveyed genes for laboratoryand in situ-tested fish collected at $\mathrm{T}_{14}$ and $\mathrm{T}_{28}$. Complete linkage was employed as amalgamation rule and Euclidean distances as metrics
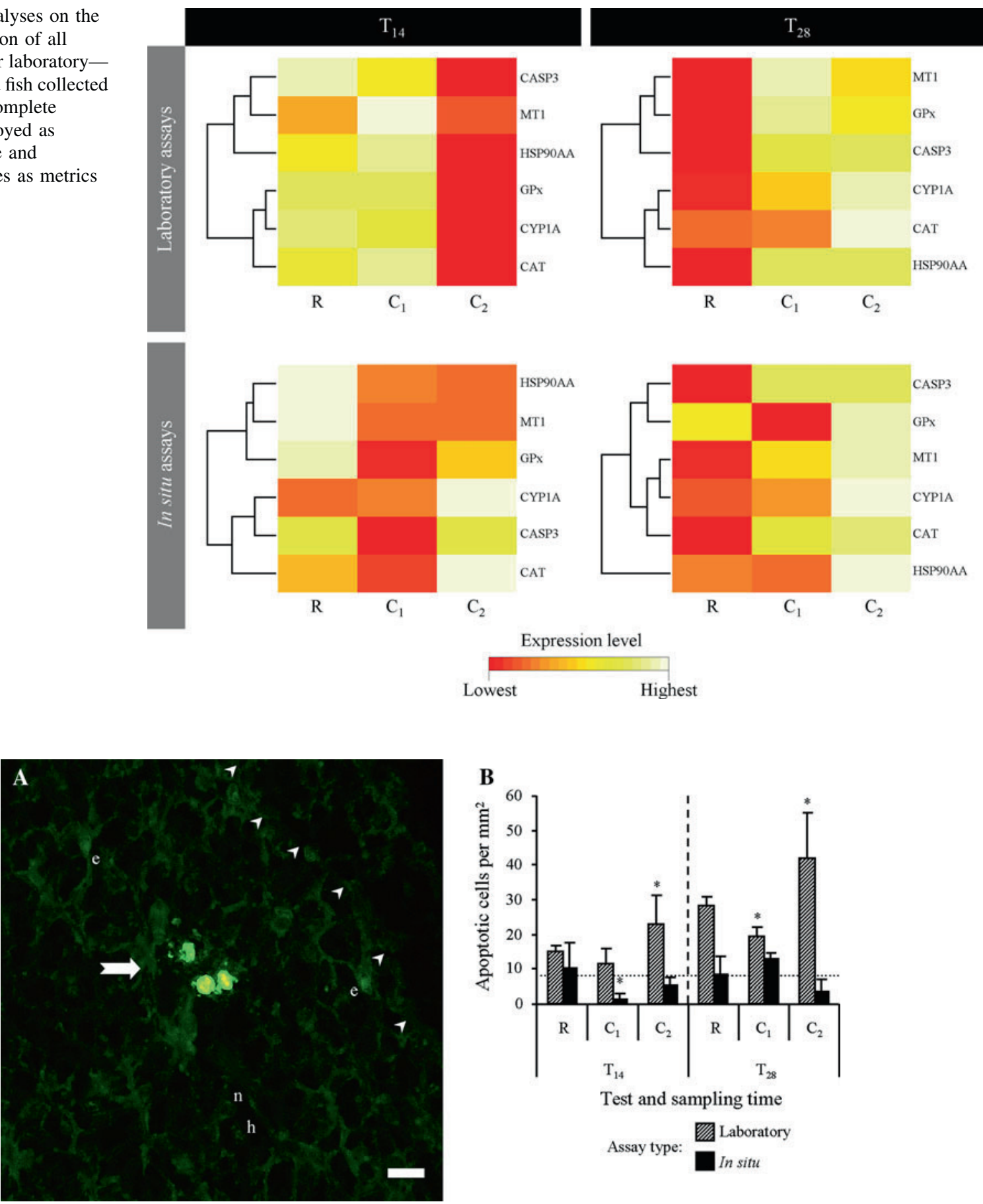

B

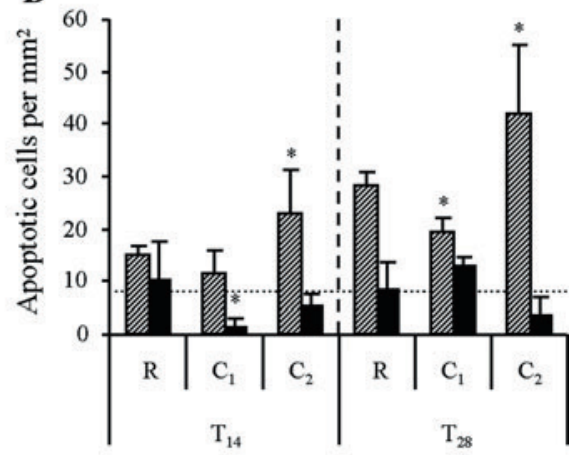

Test and sampling time

Assay type:

Laboratory
In situ
Fig. 4 Determination of hepatic apoptosis. a Apoptotic (TUNELpositive) cells in the hepatic parenchyma of a fish exposed in the laboratory to contaminated sediment $\mathrm{C}_{2}$ (arrow), compared to normal hepatocytes $(h)$ and a necrotic area (arrowheads). Erythrocytes inside sinusoid vessels can also be observed $(e)$. b Apoptotic indice (given by the number of apoptotic cells per section $\mathrm{mm}^{2}$ ) variation during

MT1 gene transcription was observed to be very significantly correlated to contamination by metals in laboratoryexposed fish (as well as GPx) and to organic contamination in field-tested animals, with the opposite trend being laboratory and in situ exposure to sediments R (reference), $\mathrm{C}_{1}$ and $\mathrm{C}_{2}$ (contaminated). The dotted line stands for the levels of apoptosis in $\mathrm{T}_{0}$ fish and is provided for comparison purposes. [*] indicate significant differences from fish exposed to the reference sediment at the same assay type and sampling time $(n=3$; Mann-Whitney $U, p<0.05)$

observed for CASP3. Also after 28 days of exposure, no significant correlations were found involving the AI in laboratory-tested animals but a significant negative correlation was found between the AI and GPx transcription in 
Table 4 Spearman rank-order correlation $\rho$ statistics between the relative transcription ratio of the surveyed genes, the hepatic apoptotic indice (AI) and the sediment quality guideline quotients (SQG-Qs) for the surveyed classes of sediment contaminants

\begin{tabular}{|c|c|c|c|c|c|c|c|c|}
\hline & \multicolumn{4}{|c|}{ Laboratory assays } & \multicolumn{4}{|c|}{ In situ assays } \\
\hline & $\mathrm{AI}$ & SQG-Q $\mathrm{Q}_{\text {Total }}$ & SQG-Q Inorganic & SQG-Q Organic & $\mathrm{AI}$ & SQG-Q $\mathrm{Q}_{\text {Total }}$ & SQG-Q $Q_{\text {Inorganic }}$ & SQG-Q Organic \\
\hline \multicolumn{9}{|c|}{ Sampling time } \\
\hline \multicolumn{9}{|l|}{$\mathrm{T}_{14}$} \\
\hline CYP1A & - & - & - & -0.84 & - & - & - & 0.90 \\
\hline MT1 & -0.95 & - & - & - & 0.69 & -0.69 & -0.69 & -0.74 \\
\hline CAT & -0.95 & - & - & - & - & - & - & - \\
\hline GPx & -0.71 & - & - & -0.71 & 0.95 & -0.95 & -0.95 & - \\
\hline CASP3 & - & - & - & -0.95 & 0.69 & -0.69 & -0.69 & - \\
\hline HSP90AA & -0.95 & - & - & - & - & - & - & -0.95 \\
\hline $\mathrm{AI}$ & & - & - & - & & -0.84 & -0.84 & - \\
\hline \multicolumn{9}{|l|}{$\mathrm{T}_{28}$} \\
\hline CYP1A & - & - & - & 0.95 & - & - & - & 0.90 \\
\hline MT1 & - & 0.95 & 0.95 & - & - & - & - & 0.95 \\
\hline CAT & - & - & - & 0.95 & - & - & - & - \\
\hline GPx & - & 0.95 & 0.95 & - & -0.95 & - & - & - \\
\hline CASP3 & - & - & - & 0.81 & - & 0.79 & 0.79 & - \\
\hline HSP90AA & - & 0.69 & 0.69 & 0.74 & -0.95 & - & - & - \\
\hline $\mathrm{AI}$ & & - & - & - & & - & - & - \\
\hline
\end{tabular}

- Non-significant correlation $(p>0.05)$

field-tested fish. Again after 28 days of exposure, in the laboratory assays, transcription of HSP90AA was found to be positively correlated to both classes of contaminants' SQG-Qs and also to the global SQG-Q, whereas no significant correlations were for observed for in situ-tested fish.

\section{Discussion}

The results revealed that the transcription of toxicity-related genes' transcription can be highly dependant on the time of exposure and assay type. However, even in face of a complex combination of toxicants, the relative regulation of the surveyed genes could be positively correlated to the levels of generalist classes of sediment-bound contaminants, showing that animals responded to chemical insult, although at a later stage of exposure. On the other hand, the observed differences between the gene transcription profiles of laboratory and in situ bioassays probably derived from two main factors: (i) differences in bioavailability and (ii) confounding factors that affected the experimental procedure, especially in the field bioassays.

Past research already reported differences between laboratory and in situ assays and the resulting difficulties to determine cause-effect relationships but the causes of such differences are not easy to pin-point (see for instance Hatch and Burton 1999). The bioavailability of inorganic and organic xenobiotics is known to be favoured by disturbance events, combined with high TOM and FF (that act as a trap for contaminants) and changes in sediment $\mathrm{pH}$ and redox status when they are re-exposed to an oxygenated medium (Eggleton and Thomas 2004; Atkinson et al. 2007). It is therefore highly probable that disturbance caused by sediment collection, handling and the animals' own scavenging activity in the test tanks, combined with constantly aerated water, favoured the release of contaminants to the water column. No noticeable sediment disturbance events were observed at the two most contaminated sites $\left(\mathrm{C}_{1}\right.$ and $\left.\mathrm{C}_{2}\right)$ but field exposure at the reference site probably introduced some degree of experimental noise related to feed. In fact, whereas small molluscs were often found in the digestive tracts of animals caged in sites $\mathrm{C}_{1}$ and $\mathrm{C}_{2}$ (of low hydrodynamics), animals allocated at the reference area and collected at $T_{28}$ contained few food items, which is likely due to the observed partial sediment washing-off from beneath the cages. Pascual et al. (2003) found that food deprivation in fish increase hepatic oxidative stress and increase the activity of GPx (but not catalase), precisely the gene whose up-regulation was stronger, in field reference-tested fish.

Different stages of stress are reflected in distinct patterns of gene transcription

When subjected to continuous stress, organisms develop their biological responses through a series of steps, or 
phases, starting from disturbance, to restitution and response and ending in an adjustment phase that should either lead to adaptation or ultimately to chronic disease. This stress phase model applies also to gene expression responses, each phase presenting a unique up- or downregulation pattern of the same genes (Steinberg et al. 2008). Fish exposed to either contaminated sediment $\left(\mathrm{C}_{1}\right.$ or $\left.\mathrm{C}_{2}\right)$ revealed very distinct patterns of transcription after 14 and 28 days of exposure, often resulting in down-regulation at $\mathrm{T}_{14}$ followed by very significant up-regulation at $\mathrm{T}_{28}$, which can be even further enhanced when converting the relative transcription ratios (RTs) to fold variation relatively to animals exposed to the reference sediment (Fig. 5). It appears possible that during the first half of the assays the animals' ability to respond to environmental stress was somehow impaired. Conversely, from the assays' mid-term onwards, fish were able to recover some hepatic metabolic balance and increase the RTs of important detoxification or xenobiotic response-related genes.

Regarding laboratory assays, the first phase (0-14 days of exposure) resulted in either absence of a clear up-regulation of the surveyed genes (in animals exposed to sediment $\mathrm{C}_{1}$ ) relatively to the reference-tested organisms or a marked down-regulation, as for the CYP1A and CAT genes in animals exposed to sediment $\mathrm{C}_{2}$. Interestingly, these are two oxidative stress-related genes related to phases I and II of detoxification, respectively, that were observed to be very significantly up-regulated in the livers of $\mathrm{C}_{2}$-exposed fish for 28 days in the laboratory. In addition, the relative transcription of both genes was found to be consistently correlated in the laboratory assays. These findings are in accordance with the positive correlations found between the SQG-Qs for organic contamination for CYP1A (in both field and laboratory) after 28 days of exposure, since these contaminants, especially PAHs (best represented in sediment $\mathrm{C}_{2}$ ) are detoxified by the CYP1A monooxygenases complex, which converts these liposoluble compounds into more hydrophilic ones (more easily excreted) with the production of ROS (e.g. Lemaire and Livingstone 1997). In the field assays, the cleavage between the "disturbance" and "recovery/response" phases is more evident for MT1 and CAT genes in test $\mathrm{C}_{1}$ and for HSP90AA and, especially, MT1 in the tests with sediment $\mathrm{C}_{2}$.

Transcription of GPx and CAT oxidative stress-related genes is linked to different classes of contaminants

The present study showed that the relative transcription of GPx and CAT genes after 28 days of exposure correlated to different classes of contaminants in the laboratory assays (metallic and inorganic, respectively), while in the field assays no significant correlations with the SQG-Qs could be retrieved. Overall, the findings from the laboratory experiments are in accordance with previous research that revealed the transcription of the two genes to be
Fig. 5 Fold change in hepatic gene transcription relatively to fish exposed to the reference sediment $(\mathrm{R})$ for laboratory and in situ tested S. senegalensis, exposed to sediment $\mathrm{C}_{1}$ (the most contaminated by metals) and sediment $\mathrm{C}_{2}$ (the most contaminated by PAHs and organochlorines), and its relation to the disturbance and recovery/response phases of stress

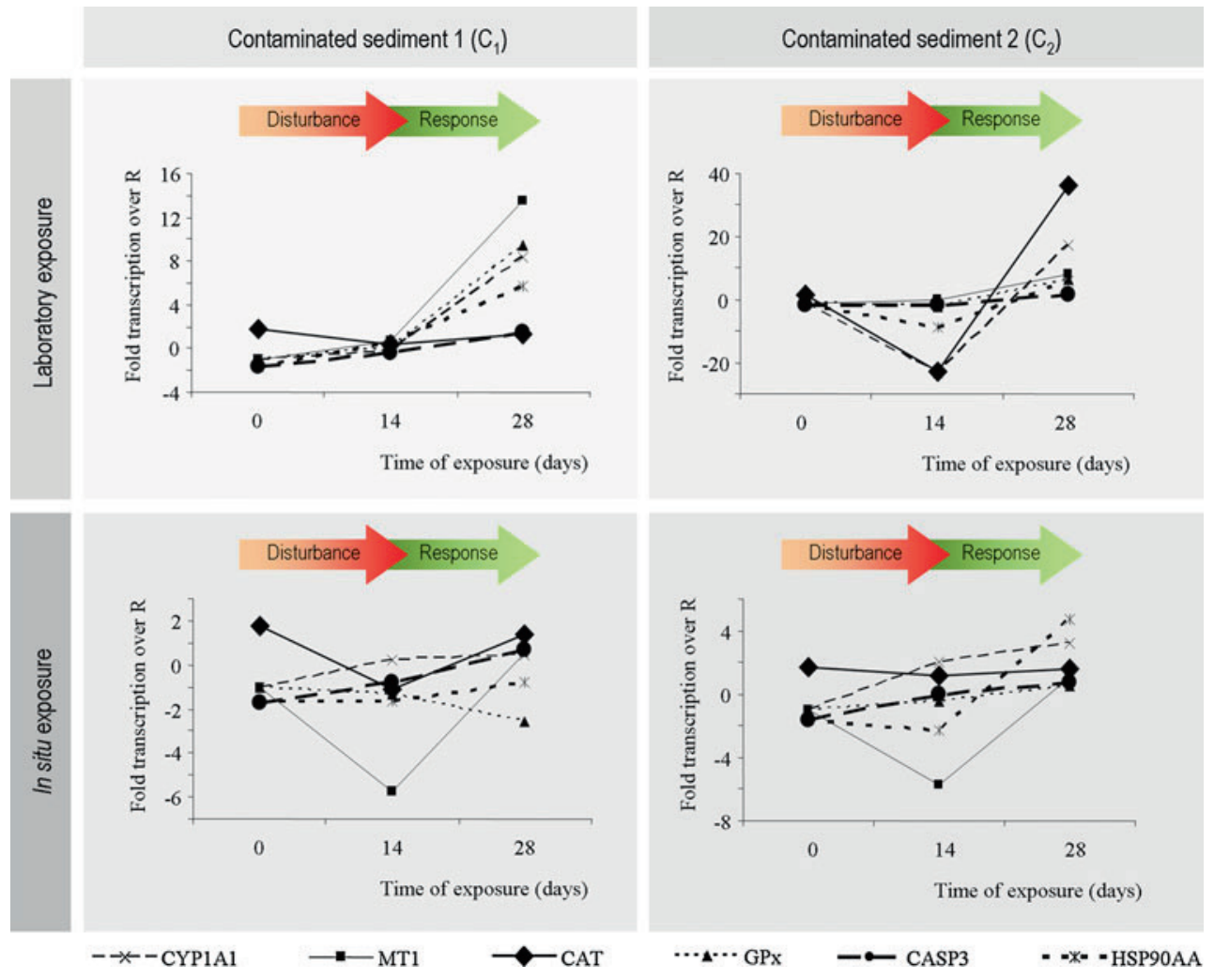


non-specifically modulated by exposure to both metallic and organic contaminants in teleosts (Hansen et al. 2007; Nahrgang et al. 2009). It is possible that CAT induction in the laboratory-exposed animals reflected, in part, the direct or indirect formation of ROS during PAH catabolism, as suggested elsewhere (Bilbao et al. 2010). Although few studies focused on CAT gene transcription as a potential biomarker, Nahrgang et al. (2009) found CAT mRNA level to be a much more consistent biomarker than the enzyme's activity in cods injected with $\mathrm{B}[\mathrm{a}] \mathrm{P}$. The present results suggest that CAT transcription may detain potential as an indicator of exposure to sediment-bound organic contaminants even when metal + organic xenobiotic mixtures are involved. The lack of any significant correlation with the SQG-Qs for the field assays (although significant up-regulation was observed in $\mathrm{C}_{1}$ and $\mathrm{C}_{2}$-tested fish) suggests caution is needed to interpret these results when multiple confounding factors are at stake. The transcription of GPx, on the other hand, was found to be correlated to metals (Table 4) and to MT transcription in laboratory-exposed fish for 28 days (refer to Fig. 3).

Increased transcription of CYP1A gene as an indicator of exposure to organic contaminants

Although one of the most consistent responses, especially in the field assays, with respect to global organic contamination, CYP1A transcription is clearly not entirely dependent on the presence of known inducers, such as PAHs, since exposure to sediment $\mathrm{C}_{1}$, almost as contaminated by these substances as $\mathrm{C}_{2}$, failed to promote a marked transcription up-regulation. Besides the differences in the sediments' geochemistry and their influence on contaminant remobilization (which differs for organic and inorganic contaminants), it is likely that the combination of metallic and organic xenobiotics had a considerable effect. In fact, in the past few years, a considerable literature sprung reporting that inhibitory or antagonistic effects between contaminants or classes of contaminants modulate the expression of CYP1A. The induction of CYP1A mRNA in vertebrate livers (including fish) has already been reported to be inhibited by metals and metalloids even in the presence of strong inducers like the aryl hydrocarbon receptor (Ahr) agonist $\mathrm{B}[\mathrm{a}] \mathrm{P}$, without, however, affecting the basal level of expression (Spink et al. 2002; Sorrentino et al. 2005). This information is in accordance with the present results considering that sediment $\mathrm{C}_{1}$ is more contaminated by metals and arsenic than $\mathrm{C}_{2}$ (although both have proximate levels of PAHs) and that exposure to sediment $\mathrm{C}_{2}$ elicited the most significant up-regulation of this gene's transcription. Flatfish have been reported to rapidly catabolize PAHs (Varanasi and Gmur 1981), which is consistent with the overall strong correlations found between the transcription of the S. senegalensis CYP1A gene and the potential risk of the surveyed levels of sediment PAHs, confirming that, in spite the presence of multiple-class contaminants, measuring CYP1A transcripts produces results that can be better related to sediment CYP inducers than measuring CYP protein content (see for instance Costa et al. 2009a).

\section{MT1 and HSP90AA as stress proteins}

Although MT induction has been surveyed as a potential biomarker of metal exposure (see for instance RomeroIsart and Vašak 2002 for a review), much research discloses difficulties to correlate MT biosynthesis with environmental metals present in low to moderate concentrations (e.g. Jessen-Eller and Crivello 1998; Mouneyrac et al. 2002; Gonzalez et al. 2006) or in fact reports its up-regulation by organic contaminants (Costa et al. 2009a). Still, the majority of research performed on MT induction in aquatic organisms for the purpose of ecological risk assessment focus on MT-like protein content and not its gene transcription. In accordance, the present results indicate that MT mRNA levels can very significantly correlate to either sediment metal + total contamination or organic contamination after 28 days of exposure, depending on assay type. This difference between laboratory and field assays is most likely caused by two main factors: (i) the differential bioavailability of metals and (ii) increased induction of MT by oxidative stress originated by organic contaminant detoxification processes. In fact, MT mRNA up-regulation has been found to change as consequence of different types of stressors in fish liver, from thermal (van Cleef-Toedt et al. 2001) to oxidative stress, with MTs being nowadays recognized scavengers for ROS (Tamai et al. 1993; Andrews 2000; Laity and Andrews 2007). Oxidative radicals produced as a consequence of CYP activity on organic toxicants may have triggered MT1 up-regulation, thus explaining the higher transcription in the livers of fish exposed to sediment $\mathrm{C}_{2}$ (most contaminated by organic contaminants) in the field for 28 days when compared to animals exposed to sediment $\mathrm{C}_{1}$ (most metal-contaminated). In fish exposed in situ for 28 days, MT1, CYP1A and the anti-oxidant phase II enzyme CAT were found to be correlated (Fig. 3), which is in accordance with this hypothesis. Conversely, in the laboratory assays MT1 transcription was correlated to the metal SQG$\mathrm{Q}$ and clustered with GPx. This information appears to confirm that MT induction might be, rather than a specific biomarker for metal exposure, a general indicator of stress, as proposed by other authors (e.g. Viarengo et al. 1999).

Heat shock proteins (HSPs) are multi-function cytosolic chaperones mainly involved in protein folding and their expression in fish as a potential biomarker for toxicological 
stress has already been proposed (Triebskorn et al. 1997; Basu et al. 2002; van der Oost et al. 2003), without, however, many clear outcomes. Eder et al. (2009), for instance, found HSP90 gene expression to be significantly elevated in the livers of salmons exposed to pesticides whereas Letcher et al. (2010) describe no alterations in HSP content or transcription in the livers of charrs exposed to organochlorines, although HSP70 and 90 contents could be elevated in the brain. Osborne et al. (2007) have inclusively found a correlation between HSP90 induction and exposure to the endocrine disruptor $17 \alpha$-ethynylestradiol in trout hepatocytes. In general, there is a great deal of information missing regarding the mechanisms of HSP action and induction in the cells. Still, the present results indicate that there is some potential of these proteins and respective mRNA quantities as an indicator of general xenobiotic-induced stress since the relative transcription of the HSP90AA gene was found to be positively correlated to all surveyed SQG-Qs (for total, metallic and organic sediment contamination) in laboratory-exposed fish for 28 days, i.e., after the disturbance phase of stress (Table 4). It is possible though, that HSP90AA transcription responds more clearly to prolonged exposure and to higher concentrations of bioavailable contaminants, as it is likely to have occurred in the laboratory-assays. It should also be noticed that, among their multiple (and not yet fully understood) functions, mammalian and fish HSP90 proteins are also known to take part in CYP1A transcription by being one of the chaperones (as dimers) of the Ahr-HSP90immunophilin-like X-associated protein 2 (XAP-2) heterodimer (Petrulis and Perdew 2002; Wiseman and Vijayan 2007). Although only in laboratory-tested fish for 28 days a correlation was found between CYP1A and HSP90AA was observed (Fig. 3), the relative expression of both genes was higher at $\mathrm{T}_{28}$ for fish exposed to sediment $\mathrm{C}_{2}$ (the most contaminated by organic substances), regardless of assay type. It is likely that the increased transcription of the HSP90AA gene was modulated, in part, to respond to the need to detoxify organic xenobiotics.

Apoptosis and the transcription of caspase 3

Although caspase 3 is a key effector caspase in the apoptotic process, either through the intrinsic (mitochondriadependant) or external (cytosolic) pathways (see Wyllie 2010), transcription of the CASP3 gene was found to be little related to the induction of apoptosis, except in fieldassayed fish after 14 days of exposure. Still, CASP3 transcription could be correlated to SQG-Qs after 28 days of exposure for both types of assays, although to different classes of contaminants (Table 4). Apoptosis (a programmed cell death pathway, PCD, in animals) may be a response mechanism to injury to avoid the dissemination of mutations, hazardous cellular debris and the inflammatory response that typically follows necrosis and that may trigger neoplasic disease itself (Hoffmann et al. 2007; Mantovani et al. 2008). It has long been suspected ROS generated by PAH activation or even metal toxicity may trigger apoptosis (Risso-de Faverney et al. 2001; Holme et al. 2007). However, it has been discussed, inclusively in flatfish, that certain contaminant interactions can actually impair the process, with prejudice to tissue recovery (e.g. Costa et al. 2010) and potentially leading to necrosis (Piechotta et al. 1999). In fact, many necrotic foci of variable extension were found in the hepatic parenchyma of animals exposed to contaminated sediments. Interestingly, heat-shock proteins, including HSP90, are also known to counterbalance apoptosis (Takayama et al. 2003 for a review). This function for HSP90 is supported by the negative correlation found between this gene's relative expression and the apoptotic indices in fish exposed in the laboratory for 14 days and in the field for 28 days (see Table 4). In fact, fish field-exposed for 28 days to sediment $\mathrm{C}_{2}$ revealed both the highest relative transcription of the CASP3 and HSP90AA genes, without any significant change in hepatocyte apoptosis comparatively to the reference treatment (Fig. 4b). Anti-oxidant defences are also known to counterbalance PCD, including MTs (Kondo et al. 1997), which could also contribute to explain the link between CASP3 relative expression and those of MT1, GPx and CAT (Fig. 3).

\section{Concluding remarks}

The present results revealed changes in S. senegalensis gene transcription was modulated by exposure and could be correlated to the sediments' levels of contamination even in face of a complex combination of toxicants, an issue that often results in responses difficult to interpret and to relate with environmental pollutants when more classical approaches are enforced. It has also been shown that complex transcriptomic patterns can arise; revealing intricate pathways of response to chemical insult that likely need further development, as for instance the role and mechanistics of apoptosis. The present findings have also shown that time-of-exposure is a crucial factor when retrieving data from bioassays, due to the clear existence of distinct phases of stress that are reflected in very different gene expression patterns. Longer exposures (28-days in the present case) produced more clear-cut responses. Finally, the choice of the adequate type of assay falls on the balance between the advantages and disadvantages of laboratory and in situ assays even though both proved adequate for surveying risk of even moderately contaminated sediment by multiple classes of substances by allowing a distinction between the reference and the contaminated sediments. 
Laboratory assays are likely to enhance bioavailability, therefore unleashing the full risk potential of a sediment and ameliorate the effects of noise variables. However, in situ assays provide a more realistic ecological risk assessment of environmental contamination (although possessing other disadvantages such as cost, response variation driven by environmental factors and even feed); therefore gaining for true predictive ecotoxicology whatever information might be lost for more mechanistic studies.

Acknowledgments The present research was approved by the Portuguese Science and Technology Foundation (FCT) and POCTI (Programa Operacional Ciência, Tecnologia e Inovação, research project ref. POCTI/AMB 57281/104) and financed by FEDER (European Fund for Regional Development). P. M. Costa is supported by a FCT PhD grant (SFRH/BD/28465/2006). For their help and support, the authors would like to thank APSS (Administração dos Portos de Setúbal e Sesimbra, SA); J. Raimundo, V. Branco, R. Cesário and P. Pousão (IPIMAR-INRB); J.P. Sampaio, A. Fonseca and M. Ferreira (DCV, FCT/UNL) and also A. Milhinhos and M. Simões (ITQB).

\section{References}

Altschul SF, Gish W, Miller W, Myers EW, Lipman DJ (1990) Basic local alignment search tool. J Mol Biol 215:403-410

Andrews GK (2000) Regulation of metallothionein gene expression by oxidative stress and metal ions. Biochem Pharmacol 59: 95-104

Atkinson CA, Jolley DF, Simpson SL (2007) Effect of overlying water $\mathrm{pH}$, dissolved oxygen, salinity and sediment disturbances on metal release and sequestration from metal contaminated marine sediments. Chemosphere 69:1428-1437

Basu N, Todgham AE, Ackerman PA, Bibeau MR, Nakano K, Shulte PM, Iwama GK (2002) Heat shock protein genes and their functional significance in fish. Gene 295:173-183

Bilbao E, Cajaraville MP, Cancio I (2010) Differential Transcription of genes involved in peroxisome proliferation in thicklip grey mullets Chelon labrosus injected with benzo(a)pyrene. Comp Biochem Physiol C 151:334-342

Brammel B, Wigginton AJ (2010) Differential gene expression in zebrafish (Danio rerio) following exposure to gaseous diffusion plant effluent and effluent receiving stream water. Am J Environ Sci 6:286-294

Cabral HN (2000) Comparative feeding ecology of sympatric Solea solea and S. senegalensis, within the nursery areas of the Tagus estuary, Portugal. J Fish Biol 57:1550-1562

Caeiro S, Costa MH, DelValls A, Repolho T, Gonçalves M, Mosca A, Coimbra AP, Ramos TB, Painho M (2009) Ecological risk assessment of sediment management areas: application to Sado Estuary, Portugal. Ecotoxicology 18:1165-1175

Caetano M, Fonseca N, Cesário R, Vale C (2007) Mobility of Pb in salt marshes recorded by total content and stable isotopic signature. Sci Total Environ 380:84-92

Cerdà J, Chauvigne F, Agulleiro MJ, Marin E, Halm S, MartínezRodríguez G, Prat F (2008) Molecular cloning of Senegalese sole (Solea senegalensis) follicle-stimulating hormone and luteinizing hormone subunits and expression pattern during spermatogenesis. Gen Comp Endocrinol 156:470-481

Cerdà J, Douglas S, Reith M (2010) Genomic resources for flatfish research and their applications. J Fish Biol 77:1045-1070
Chairi H, Fernández-Diaz C, Navas JI, Manchado M, Rebordinos L, Blasco J (2010) In vivo genotoxicity and stress defences in three flatfish species. Ecotoxicol Environ Saf 73:1279-1285

Chapman PM (2007) Determining when contamination is pollutionweight of evidence determinations for sediments and effluents. Environ Int 33:492-501

Costa PM, Caeiro S, Diniz M, Lobo J, Martins M, Ferreira AM, Caetano M, Vale C, DelValls TÀ, Costa MH (2009a) Biochemical endpoints on juvenile Solea senegalensis exposed to estuarine sediments: the effects of contaminant mixtures on metallothionein and CYP1A induction. Ecotoxicology 18: 988-1000

Costa PM, Diniz MS, Caeiro S, Lobo J, Martins M, Ferreira AM, Caetano M, Vale C, DelValls TÀ, Costa MH (2009b) Histological biomarkers in liver and gills of juvenile Solea senegalensis exposed to contaminated estuarine sediments: a weighted indices approach. Aquat Toxicol 92:202-212

Costa PM, Chicano-Gálvez E, López Barea J, DelValls TÀ, Costa MH (2010) Alterations to proteome and tissue recovery responses in fish liver caused by a short-term combination treatment with cadmium and benzo[a]pyrene. Environ Pollut 158:3338-3346

Costley CT, Mossop KF, Dean JR, Garden LM, Marshall J, Carroll J (2000) Determination of mercury in environmental and biological samples using pyrolysis atomic adsorption spectrometry with gold amalgamation. Anal Chim Acta 405:179-183

Eder KJ, Leutenegger CM, Köhler H-R, Wener I (2009) Effects of neurotoxic insecticides on heat-shock proteins and cytokine transcription in Chinook salmon (Oncorhynchus tshawytscha). Ecotoxicol Environ Saf 17:182-190

Eggleton J, Thomas KV (2004) A review of factors affecting the release and bioavailability of contaminants during sediment disturbance events. Environ Int 30:973-980

Ferreira AM, Martins M, Vale C (2003) Influence of diffuse sources on levels and distribution of polychlorinated biphenyls in the Guadiana River estuary, Portugal. Mar Chem 89:175-184

Filby AL, Santos EM, Thorpe KL, Maack G, Tyler CR (2007) Gene expression profiling for understanding chemical causation of biological effects for complex mixtures: a case study on estrogens. Environ Sci Technol 41:8187-8194

Forné I, Agulleiro MJ, Asensio E, Abián J, Cerdà J (2009) 2-D DIGE analysis of Senegalese sole (Solea senegalensis) testis proteome in wild-caught and hormone-treated F1 fish. Proteomics 9: 2171-2181

Gatzidou ET, Zira AN, Theocharis SE (2007) Toxicogenomics: a pivotal piece in the puzzle of toxicological research. J Appl Toxicol 27:302-309

Gonzalez P, Baudrimont M, Boudou A, Bourdineaud J-P (2006) Comparative effects of direct cadmium contamination on gene expression on gills, liver, skeletal muscles and brain of the zebrafish (Danio rerio). Biometals 19:225-235

Häcker G (2000) The morphology of apoptosis. Cell Tissue Res 301:5-17

Hallare AV, Seiler T-B, Hollert H (2011) The versatile, changing, and advancing roles of fish in sediment toxicity assessment-a review. J Soils Sed 11:141-173

Hansen BH, Rømma S, Garmo ØA, Pedersen SA, Olsvik PA, Andersen RA (2007) Induction and activity of oxidative stressrelated proteins during waterborne $\mathrm{Cd} / \mathrm{Zn}$-exposure in brown trout (Salmo trutta). Chemosphere 67:2241-2249

Hatch AC, Burton GA Jr (1999) Sediment toxicity and storm water runoff in a contaminated receiving system: consideration of different bioassays in the laboratory and field. Chemosphere 39:1001-1017

Hoffmann A, Xia Y, Verma IM (2007) Inflammatory tales of liver cancer. Cancer Cell 11:99-101 
Holme JA, Gorria M, Arlt VM, Øvrebø S, Solhaug A, Tekpli X, Landvik NE, Huc L, Fardel O, Lagadic-Gossmann D (2007) Different mechanisms involved in apoptosis following exposure to benzo[a]pyrene in F258 and Hepa1c1c7 cells. Chem-Biol Interact 167:41-55

Jessen-Eller K, Crivello JF (1998) Changes in MT mRNA and protein after sublethal exposure to arsenite and cadmium chloride in juvenile winter flounder. Environ Toxicol Chem 17:891-896

Kalman J, Riba I, DelValls TÁ, Blasco J (2010) Comparative toxicity of cadmium in the commercial fish species Sparus aurata and Solea senegalensis. Ecotoxicol Environ Saf 73:306-311

Kondo Y, Rusnak JM, Hoyt DG, Settineri CE, Pitt BR, Lazo JS (1997) Enhanced apoptosis in metallothionein null cells. Mol Pharmacol 52:195-201

Laity JH, Andrews GK (2007) Understanding the mechanisms of zinc-sensing by metal-response element binding transcription factor-1 (MTF-1). Arch Biochem Biophys 463:201-210

Lemaire P, Livingstone DR (1997) Aromatic hydrocarbon quinonemediated reactive oxygen species production in hepatic microsomes of the flounder (Platichthys flesus L.). Comp Biochem Physiol C 117:131-139

Letcher RJ, Bustnes JO, Dietz R, Jenssen BM, Jørgensen EH, Sonne C, Verreault J, Vijayan MM, Gabrielse GW (2010) Exposure and effects assessment of persistent organohalogen contaminants in arctic wildlife and fish. Sci Total Environ 408:2995-3043

Long ER, MacDonald DD (1998) Recommended uses of empirically derived, sediment quality guidelines for marine and estuarine ecosystems. Hum Ecol Risk Assess 4:1019-1039

Macdonald DD, Carr S, Calder F, Long E, Ingersoll C (1996) Development and evaluation of sediment quality guidelines for Florida coastal waters. Ecotoxicology 5:253-278

MacDonald DD, Carr RS, Eckenrod D, Greening H, Grabe S, Ingersoll CG, Janicki S, Janicki T, Lindskoog RA, Long ER, Pribble R, Sloane G, Smorong DE (2004) Development, evaluation, and application of sediment quality targets for assessing and managing contaminated sediments in Tampa Bay, Florida. Arch Environ Contam Toxicol 46:147-161

Manchado M, Salas-Leiton E, Infante C, Ponce M, Asensio E, Crespo A, Zuasti E, Cañavate JP (2008) Molecular characterization, gene expression and transcriptional regulation of cytosolic HSP90 genes in the flatfish Senegalese sole (Solea senegalensis Kaup). Gene 416:77-84

Mantovani A, Allavena P, Sica A, Balkwill F (2008) Cancer-related inflammation. Nature 454:436-444

Martins M, Ferreira AM, Vale C (2008) The influence of Sarcocornia fruticosa on retention of PAHs in salt marshes sediments (Sado estuary, Portugal). Chemosphere 71:1599-1606

Miller HC, Mills GN, Bembo DG, Macdonald JA, Evans CW (1999) Induction of P4501A (CYP1A) in Trematomus bernachii as an indicator on environmental pollution in Antarctica: assessment by quantitative RT-PCR. Aquat Toxicol 44:183-193

Mouneyrac C, Amiard JC, Amiard-Triquet C, Cottier A, Rainbow PS, Smith BD (2002) Partitioning of accumulated trace metals in the talitrid amphipod crustacean Orchestia gammarellus: a cautionary tale on the use of metallothionein-like proteins as biomarkers. Aquat Toxicol 57:225-242

Nahrgang J, Camus L, Gonzalez P, Goksøyr A, Christiansen JS, Hop $\mathrm{H}$ (2009) PAH biomarker responses in polar cod (Boreogadus saida) exposed to benzo(a)pyrene. Aquat Toxicol 94:309319

Oliva M, González de Canales ML, Gravato C, Guilhermino L, Perales JA (2010) Biochemical effects and polycyclic aromatic hydrocarbons (PAHs) in Senegal sole (Solea senegalensis) from a Huelva estuary (SW Spain). Ecotoxicol Environ Saf 72: $1842-1851$
Osborne N, Sherry J, Rendell JL, Currie S (2007) The role of hsp90 in $17 \alpha$-ethynylestradiol-induced endocrine disruption in rainbow trout hepatocytes. Ecotoxicol Environ Saf 68:13-19

Osuna-Jiménez I, Williams TD, Prieto-Álamo M-J, Abril N, Chipman K, Pueyo C (2009) Immune- and stress-related transcriptomic responses of Solea senegalensis stimulated with lipopolysaccharide and copper sulphate using heterologous cDNA microarrays. Fish Shell Immunol 26:699-706

Pascual P, Pedrajas JR, Toribio F, López-Barea J, Peinado J (2003) Effect of food deprivation on oxidative stress biomarkers in fish (Sparus aurata). Chem-Biol Interact 145:191-199

Petrulis JR, Perdew GH (2002) The role of chaperone proteins in the aryl hydrocarbons receptor core complex. Chem-Biol Interact $141: 25-40$

Pfaffl MW (2001) A new mathematical model for relative quantification in real-time RT-PCR. Nucleic Acids Res 29:e45

Piechotta G, Lacorn M, Lang T, Kammann U, Simat T, Jenke H-S, Steinhart H (1999) Apoptosis in dab (Limanda limanda) as possible new biomarker for anthropogenic stress. Ecotoxicol Environ Saf 42:50-56

Polpitiya AD, Qian WJ, Jaitly N, Petyuk VA, Adkins JN, Camp DG II, Anderson GA, Smith RD (2008) DAnTE: a statistical tool for quantitative analysis of -omics data. Bioinformatics 24:1556-1558

Prieto-Álamo M-J, Abril N, Osuna-Jiménez I, Pueyo C (2009) Solea senegalensis genes responding to lipopolysaccharide and copper sulphate challenges: large-scale identification by suppression subtractive hybridization and absolute quantification of transcriptional profiles by real-time RT-PCR. Aquat Toxicol 91:312-319

Riba I, Casado-Martínez MC, Blasco J, DelValls TA (2004) Bioavailability of heavy metals bound to sediments affected by a mining spill using Solea senegalensis and Scrobicularia plana. Mar Environ Res 58:395-399

Risso-de Faverney C, Devaux A, Lafaurie M, Girard JP, Bailly B, Rahmani R (2001) Cadmium induces apoptosis and genotoxicity in rainbow trout hepatocytes through generation of reactive oxygen species. Aquat Toxicol 53:65-76

Romero-Isart N, Vašak M (2002) Advances in the structure and chemistry of metallothioneins. J Inorg Biochem 88:386-396

Salas-Leiton E, Cánovas-Conesa B, Zerolo R, López-Barea J, Cañavate JP, Alhama J (2009) Proteomics of juvenile Senegal sole (Solea senegalensis) affected by gas bubble disease in hyperoxygenated ponds. Mar Biotechnol 11:473-487

Snell TW, Brogdon SE, Morgan MB (2003) Gene expression profiling in ecotoxicology. Ecotoxicology 12:475-483

Sorrentino C, Roy NK, Courtenay SC, Wirgin I (2005) Co-exposure to metals modulated CYP1A mRNA inducibility in Atlantic tomcod Microgadus tomcod from two populations. Aquat Toxicol 75:238-252

Spink DC, Katz BH, Hussain MM, Spink BC, Wu S, Liu N, Pause R, Kaminsky RP (2002) Induction of CYP1A1 and CYP1B1 in T-47D human breast cancer cells by benzo[a]pyrene is diminished by arsenite. Drug Metab Dispos 30:262-269

Steinberg CEW, Stürzenbaum SR, Menzel R (2008) Genes and environment-striking the fine balance between sophisticated biomonitoring and true functional environmental genetics. Sci Total Environ 400:142-161

Takayama S, Reed JC, Homma S (2003) Heat-shock proteins as regulators of apoptosis. Oncogene 22:9041-9047

Tamai KT, Gralla EB, Ellerby LM, Valentine JR, Thiele DJ (1993) Yeast and mammalian metallothioneins functionally substitute for yeast copper-zinc superoxide dismutase. Proc Natl Acad Sci USA 90:8013-8017

Tamura K, Dudley J, Nei M, Kumar S (2007) MEGA4: molecular evolutionary genetics analysis (MEGA) software version 4.0. Mol Biol Evol 24:1596-1599 
Triebskorn R, Köhler H-R, Honnen W, Schramm M, Adams SM, Müller EF (1997) Induction of heat shock proteins, changes in liver ultrastructure and alterations of fish behavior: are these biomarkers related and are they useful to reflect the state of pollution in the field? J Aquat Ecosys Stress Recov 6:57-73

van Cleef-Toedt KA, Kaplan LAE, Crivello JF (2001) Killifish metallothionein messenger RNA expression following temperature perturbation and cadmium exposure. Cell Stress Chaperones 6:351-359

van der Oost R, Beyer J, Vermeulen NPE (2003) Fish bioaccumulation and biomarkers in environmental risk assessment: a review. Environ Toxicol Pharmacol 13:57-149

Varanasi U, Gmur DJ (1981) Hydrocarbons and metabolites in English sole (Parophrys vetulus) exposed simultaneously to $\left[{ }^{3} \mathrm{H}\right]$ benzo[a]pyrene and $\left[{ }^{14} \mathrm{C}\right]$ naphthalene in oil-contaminated sediment. Aquat Toxicol 1:49-67

Viarengo A, Burlando B, Dondero F, Marro A, Fabbri R (1999) Metallothionein as a tool in biomonitoring programmes. Biomarkers 4:455-466

Wirgin I, Waldman JR (1998) Altered gene expression and genetic damage in North American fish populations. Mutat Res 399:193-219

Wiseman SB, Vijayan MM (2007) Aryl hydrocarbon receptor signalling in rainbow trout hepatocytes: role of hsp90 and the proteasome. Comp Biochem Physiol C 146:484-491

Wyllie AH (2010) "Where, o death, is thy sting?" A brief review of apoptosis biology. Mol Neurobiol 42:4-9

Zar JH (1998) Biostatistical analysis, 4th edn. Prentice Hall, Upper Saddle River 